\title{
Effect of using knee valgus brace on pain and activity level over different time intervals among patients with medial knee OA: systematic review
}

Huda Alfatafta ${ }^{1 *}$, David Onchonga ${ }^{1}$, Mahmoud Alfatafta ${ }^{2}$, lu Zhang ${ }^{1}$, Imre Boncz ${ }^{3}$, Szimonetta Lohner ${ }^{4}$ and Bálint Molics ${ }^{5}$

\begin{abstract}
Background: The Knee valgus brace is one of the accepted conservative interventions for patients with medial compartment knee osteoarthritis to correct the knee varus and increase functional activity level. Nevertheless, comprehensive overview of the effects of using this brace on self-reported pain activity level over time is not available. Thus, this study aimed to systematically review the effect of using this brace on pain and activity levels in the last 20 years in patients with medial compartment knee osteoarthritis.
\end{abstract}

Methods: Five databases were searched to find articles from the year 2000 to the end of November 2020: Cochrane Central Register of Controlled Trials (CENTRAL), EMBASE, PubMed, Web of Science, and Scopus. Two reviewers independently evaluated the available articles for eligibility and assessed quality. The risk of bias in each study was assessed by two reviewers independently according to the Strengthening the Reporting of Observational Studies in Epidemiology tool (STROBE) for the non-randomized controlled studies and the Cochrane risk-of-bias tool for the randomized controlled studies.

Results: Seven randomized controlled studies and 17 cohort studies (in total 579 participants) were included in the systematic review. Most of these studies found using a knee valgus brace effective in reducing pain and improving activity level over different time intervals. The majority of the included studies (14 studies) evaluated the impact of the brace for a considerably short-term (less than 6 months). Thus, limited evidence is available on the long-term use of the knee valgus brace and its associated complications.

Conclusion: The knee valgus brace is an effective conservative intervention to improve the quality of life and reduce pain during daily activities for some patients. However, the long term of using this brace is still not very convenient, and the patients who benefit most from using the brace should be identified with high methodological quality studies.

Keywords: Knee-valgus brace, Pain, Activity level

*Correspondence: huda.alfatafta@etk.pte.hu

1 Doctoral School of Health Sciences, Faculty of Health Sciences, University of Pécs, Vörösmarty utca 4, 7621 Pécs, Hungary

Full list of author information is available at the end of the article

\section{Background}

Knee osteoarthritis is the most common reason for disability, pain, and limited activity level among the elderly. The medial compartment of the knee joint is 10 times more likely to be affected by osteoarthritis (OA) than original author(s) and the source, provide a link to the Creative Commons licence, and indicate if changes were made. The images or other third party material in this article are included in the article's Creative Commons licence, unless indicated otherwise in a credit line to the material. If material is not included in the article's Creative Commons licence and your intended use is not permitted by statutory regulation or exceeds the permitted use, you will need to obtain permission directly from the copyright holder. To view a copy of this licence, visit http://creativecommons.org/licenses/by/4.0/. The Creative Commons Public Domain Dedication waiver (http://creativeco mmons.org/publicdomain/zero/1.0/) applies to the data made available in this article, unless otherwise stated in a credit line to the data. 
the lateral compartment because it receives almost 70\% of the total joint load during walking [1-3]. In Europe, it has been seen that $25 \%$ of elderly over 50 years have severe knee OA yearly [4], and women are more affected than men ( $6.6 \%$ vs. $4.9 \%$, woman vs. men, respectively) [5]. During medial knee OA, the medial space of the knee joint is narrowing due to cartilage degeneration that leads to a high varus moment $[1,3,6]$. This high varus moment generates pain during daily activity and sometimes during rest in severe cases. Moreover, it has been suggested that patients with knee OA complain from knee instability during daily activities which are correlated with knee pain and low quality of life [7]. Thus, using the knee valgus brace increases the knee's mediolateral stability and reduces the pain [7].

The primary questionnaires that are used to evaluate pain and activity level are the Western Ontario and McMaster Universities Osteoarthritis Index (WOMAC), visual analogue pain score (VAS), the short form 36 (SF36), and the Knee injury and Osteoarthritis Outcome Score (KOOS). Those questionnaires have high validity and reliability [8-11], and examine the pain and the activity in the last previous week; hence, the patients can remember their experiences with pain and their daily activities $[8,10,12,13]$.

Various interventions (surgical and non-surgical) are recommended based on the Osteoarthritis Research Society International (OARSI) guidelines such as surgical interventions, physiotherapy, orthotics (foot orthoses, knee braces), pain killers, and self-managements. Those interventions aim to reduce pain, improve activity level, and slow disease progressions $[14,15]$.

The Knee valgus brace is one of the accepted conservative interventions for patients with medial compartment knee OA to improve quality of life and reduce the load on the medial compartment of the knee joint $[1,6]$. This brace is used to correct the knee varus through applying valgus force with two methods: bending system (three-point pressure system) directly to the knee joint or through applying valgus force and external rotation of the leg $[1,6,16,17]$. Both designs aim to reduce the knee varus alignment, unload the medial compartment of the knee and decrease the symptoms $[1,6,16]$. The knee valgus brace could be an off-the-shelf or custommade brace. Most of the studies recommend using the custom-made knee valgus brace because it shows better fitting, knee varus correction and better activity level improvement $[3,6,18]$. The available systematic review and meta-analysis studies evaluated all kind of knee braces (such as soft, dynamic, valgus, etc.) that are used for patients with medial compartment knee OA, but there is no study evaluate only the effect of knee valgus brace over a different time interval. Thus, the aim of this study is critically evaluating the studies that only assessed the effect of knee valgus brace on pain and activity level among medial knee OA participants in the last 20 years (from 2000-2020). The time interval of using a knee valgus brace will be determined as short-term use (less than 3 months), moderate time use (3-6 months), and longterm use (more than 6 months).

\section{Methods}

The PRISMA (Preferred Reporting Items for Systematic Reviews and Misanalyses) guidelines were used to report the methodology and the results of the systematic review.

\section{Search strategy}

Two independent reviewers searched the following electronic databases from January 2000 until the end of November 2020: Cochrane Central Register of Controlled Trials (CENTRAL), EMBASE, PubMed, Web of Science and Scopus. The used search strategy is available in Additional file 1: Appendix 1 and the search strategy was adapted for the different databases as required.

\section{Study screening}

Two authors independently selected studies based on predefined inclusion criteria. The titles and abstracts were reviewed first, and irrelevant references were excluded. Then full-text publications of potentially relevant studies were obtained and checked for final inclusion. The references and related articles of the selected studies were screened for more suitable studies. Any disagreement was resolved by discussion among the two authors. If they could not reach an agreement, the third author was consulted and a decision was made by a discussion and majority vote. Authors were contacted if the data were not clear or further information were required.

\section{Eligibility criteria}

All studies (randomized-controlled-trials (RCTs), controlled clinical trials (CCTs) and other study designs, such as cohort studies and case-control studies) that evaluated the effects of knee valgus brace on pain and functional activities were included and they have had to be written in English. Also, they had to meet all of the following criteria: (a) adult participants with medial compartment knee osteoarthritis, (b) participants with pain, morning stiffness, and activity level limitations, (c) the outcomes of pain and/or activity level are measured using WOMAC, SF36, KOOS, or VAS, (d) publication between January 2000-end of November 2020.

The study was excluded if (a) it looked at evaluating the knee valgus brace combined with another treatment or medication, (b) studies with children, (c) evaluation the pain and the activity level with other questionnaires, (d) 
using different kind of knee orthoses instead of knee valgus brace, (e) patients with lateral compartment knee OA or have OA in other joints such as hip or ankle joints. No restrictions if the knee $\mathrm{OA}$ is with clinical or/and radiological symptoms.

\section{Data extraction and risk-of-bias assessment}

Two reviewers independently extracted data from the selected studies or reports according to a fixed protocol. The following information was extracted: study design, number of participants, patients' demographic, the health status of participants, type of knee brace, duration, pain score, activity level scores and funding resources.

The risk of bias in each study was assessed by two reviewers independently according to the Strengthening the Reporting of Observational Studies in Epidemiology tool (STROBE) for the non-randomized controlled studies and the Cochrane risk-of-bias tool for the randomized controlled studies. STROBE evaluates the good reporting of the observational studies and has 22 items to assess the reporting quality of title and abstract, introduction, methods, results and discussion sections $[19,20]$. The

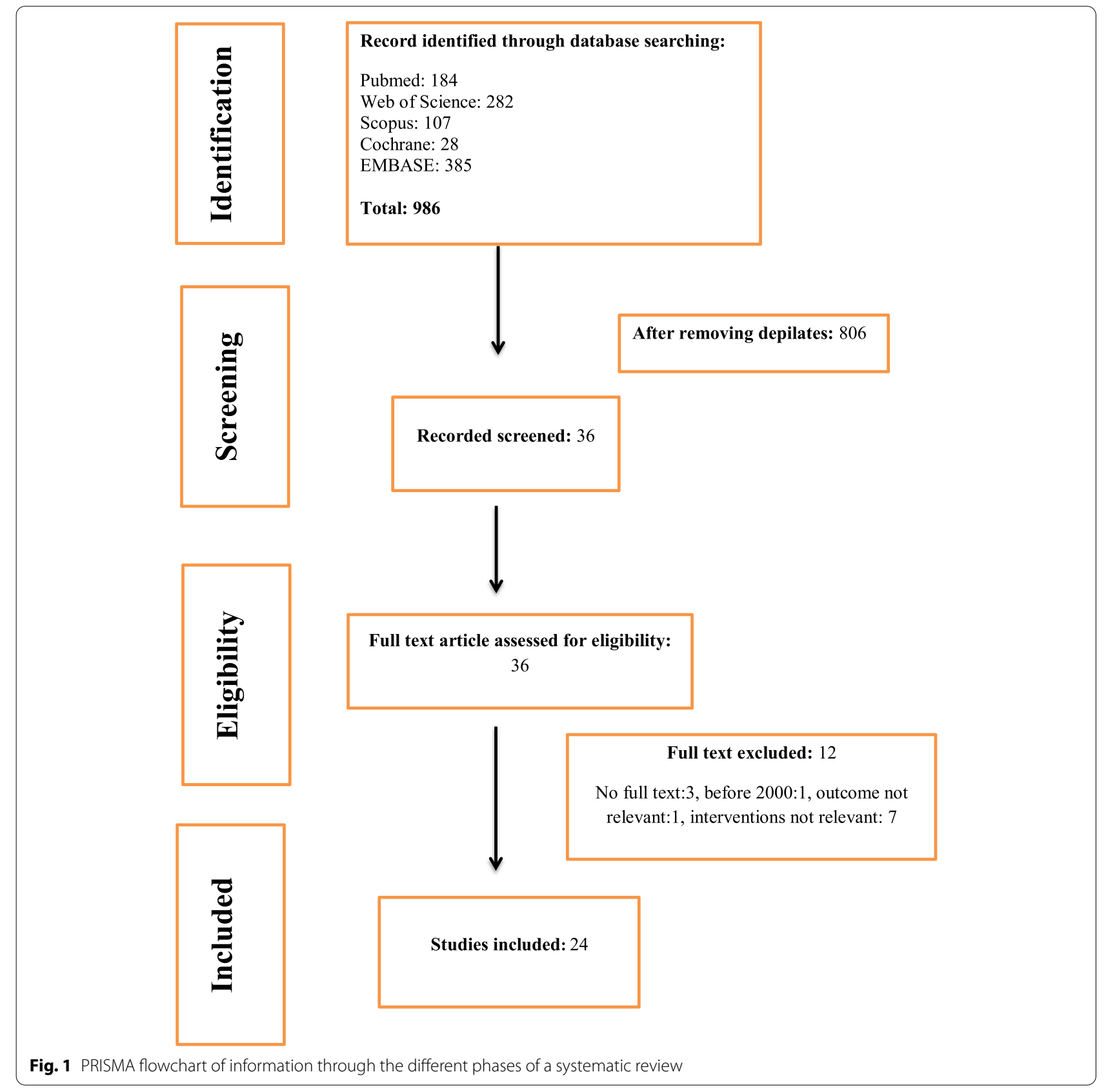


Table 1 Observational and randomized studies on the association of using knee valgus brace and questionnaires (WOMAC, VAS, SF-36, KOOS). $\uparrow$ means that a positive, significant change was described in the manuscript between before and after values; - means that the outcomes improved but not significantly; $\downarrow$ means that a significant negative change was described in the publications. F: means female, M: means male

\begin{tabular}{|c|c|c|c|c|c|c|}
\hline $\begin{array}{l}\text { First author, } \\
\text { publication year } \\
\text { (reference no) }\end{array}$ & Study design & $\begin{array}{l}\text { Number of } \\
\text { participants }\end{array}$ & $\begin{array}{l}\text { Intervention } \\
\text { duration }\end{array}$ & $\begin{array}{l}\text { Type of the knee } \\
\text { valgus brace }\end{array}$ & $\begin{array}{l}\text { Used- } \\
\text { questionnaire }\end{array}$ & $\begin{array}{l}\text { The direction of } \\
\text { effect, as indicated } \\
\text { in the manuscript }\end{array}$ \\
\hline Jones et al.,2013 [6] & $\begin{array}{l}\text { crossover rand- } \\
\text { omized }\end{array}$ & $28(12 f, 16 \mathrm{~m})$ & 2 weeks & $\begin{array}{l}\text { Donjoy-OA } \\
\text { Adjuster, DJO, } \\
\text { Vista, USA) }\end{array}$ & $\begin{array}{l}\text { WOMAC } \\
\text { VAS pain }\end{array}$ & $\uparrow$ \\
\hline $\begin{array}{l}\text { Haladik et al. } 2014 \\
\text { [1] }\end{array}$ & prospective cohort & $10(1 f, 9 m)$ & 2 weeks & OA Adjuster & WOMAC & $\uparrow$ \\
\hline Fu et al., 2015 [21] & $\begin{array}{l}\text { non-randomized } \\
\text { prospective } \\
\text { cohort }\end{array}$ & $10(4 f, 6 m)$ & 4 weeks & $\begin{array}{l}\text { Unloader valgus } \\
\text { knee braces } \\
\text { (Ossurhf, Reykja- } \\
\text { vik, Iceland) }\end{array}$ & $\begin{array}{l}\text { WOMAC } \\
\text { VAS pain }\end{array}$ & $\uparrow$ \\
\hline Polloet al., 2002 [22] & prospective cohort & $11(1 \mathrm{f}, 10 \mathrm{~m})$ & 2 weeks & $\begin{array}{l}\text { Generation II Un- } \\
\text { loader ADJ brace, } \\
\text { Generation II US }\end{array}$ & VAS pain & $\uparrow$ \\
\hline $\begin{array}{l}\text { Schmalz et al., } 2010 \\
\text { [23] }\end{array}$ & prospective cohort & $16(8 f, 8 \mathrm{~m})$ & 4 weeks & $\begin{array}{l}\text { Genu Arthro knee } \\
\text { brace }\end{array}$ & VAS pain & $\uparrow$ \\
\hline $\begin{array}{l}\text { Ramsey et al., } 2007 \\
\text { [7] }\end{array}$ & prospective cohort & 16 (not available) & 2 weeks & $\begin{array}{l}\text { Generationll } \\
\text { Unloader Select, } \\
\text { Generation II } \\
\text { USA, Inc., Bothell, } \\
\text { Washington }\end{array}$ & KOOS & - \\
\hline $\begin{array}{l}\text { Hsieh et al.,2020 } \\
\text { [24] }\end{array}$ & comparative study & $20(13 f, 7 m)$ & $\begin{array}{l}1 \text { month and } \\
3 \text { months }\end{array}$ & $\begin{array}{l}\text { Thruster Legacy OA } \\
\text { brace }\end{array}$ & $\begin{array}{l}\text { WOMAC } \\
\text { VAS pain }\end{array}$ & $\uparrow$ \\
\hline $\begin{array}{l}\text { Briggs et al. } 2012 \\
{[25]}\end{array}$ & prospective cohort & $39(16 f, 23$ m) & $\begin{array}{l}3 \text { week, } 6 \text { weeks, } \\
\text { and } 6 \text { months }\end{array}$ & unloader brace & $\begin{array}{l}\text { WOMAC } \\
\text { SF36 }\end{array}$ & $\uparrow$ \\
\hline $\begin{array}{l}\text { van Egmondet al., } \\
2017 \text { [26] }\end{array}$ & $\begin{array}{l}\text { randomized con- } \\
\text { trolled trial }\end{array}$ & $\begin{array}{l}\text { 100.In Bledsoe } \\
\text { Thrustergroup } \\
50(20 f, 30 \mathrm{~m}) \text {. } \\
\text { InSofTec group } \\
50(22 \mathrm{f}, 28 \mathrm{~m})\end{array}$ & $\begin{array}{l}2 \text { weeks and } \\
12 \text { weeks }\end{array}$ & $\begin{array}{l}\text { the Bledsoe } \\
\text { Thrusterbrace } \\
\text { (B\&Co Inc. N.V., } \\
\text { Sint-Antelinks, } \\
\text { Belgium) } \\
\text { andtheSofTec OA } \\
\text { Brace (Bauerfeind } \\
\text { AG, Zeulenroda- } \\
\text { Triebes, Germany) }\end{array}$ & $\begin{array}{l}\text { VAS pain } \\
\text { WOMAC } \\
\text { SF-36 }\end{array}$ & $\uparrow$ \\
\hline $\begin{array}{l}\text { Barne et al., } 2002 \\
\text { [27] }\end{array}$ & prospective cohort & $30(12 f, 18 m)$ & 8 weeks & $\begin{array}{l}\text { Counterforce brace } \\
\text { (breg, calif) }\end{array}$ & SF-36 & $\uparrow$ \\
\hline $\begin{array}{l}\text { Thoumie et al., } 2018 \\
\text { [28] }\end{array}$ & $\begin{array}{l}\text { randomized con- } \\
\text { trolled trial }\end{array}$ & $32(24 f, 8 m)$ & 6 weeks & $\begin{array}{l}\text { The REBELRELIEVER } \\
\text { unloading knee } \\
\text { brace }\end{array}$ & VAS pain (100 mm) & $\uparrow$ \\
\hline $\begin{array}{l}\text { Gaasbeek et al.,2007 } \\
\text { [16] }\end{array}$ & prospective cohort & $15(3 f, 12 m)$ & 6 weeks & $\begin{array}{l}\text { The SofTec OA } \\
\text { valgus brace }\end{array}$ & $\begin{array}{l}\text { WOMAC } \\
\text { VAS pain }\end{array}$ & $\uparrow$ \\
\hline $\begin{array}{l}\text { Laroche et al., } 2014 \\
\text { [29] }\end{array}$ & prospective cohort & $20(16 f, 5 \mathrm{~m})$ & 5 weeks & $\begin{array}{c}\text { PROTEOR (France)/ } \\
\text { ODRA }{ }^{\circledR} \text { brace }\end{array}$ & WOMAC & $\uparrow$ \\
\hline $\begin{array}{l}\text { Draganich } \\
\text { et al.,2006 [18] }\end{array}$ & Crossover & 10 (not available) & 5 weeks & $\begin{array}{l}\text { Adjustable OA } \\
\text { Defiance; dj } \\
\text { Orthopedics) }\end{array}$ & WOMAC & $\uparrow$ \\
\hline $\begin{array}{l}\text { Ornetti et al., } 2015 \\
\text { [30] }\end{array}$ & prospective cohort & $20(16 f, 4 \mathrm{~m})$ & $\begin{array}{l}6 \text { weeks and } \\
52 \text { weeks }\end{array}$ & OdrA brace & $\begin{array}{l}\text { KOOS } \\
\text { VAS pain }\end{array}$ & $\uparrow$ \\
\hline $\begin{array}{l}\text { Arazpour et al., } \\
2013 \text { [31] }\end{array}$ & $\begin{array}{l}\text { randomized pro- } \\
\text { spective cohort }\end{array}$ & $12(8 f, 4 \mathrm{~m})$ & 6 weeks & $\begin{array}{l}\text { Custom-made knee } \\
\text { valgus brace }\end{array}$ & VAS pain & $\uparrow$ \\
\hline
\end{tabular}


Table 1 (continued)

\begin{tabular}{|c|c|c|c|c|c|c|}
\hline $\begin{array}{l}\text { First author, } \\
\text { publication year } \\
\text { (reference no) }\end{array}$ & Study design & $\begin{array}{l}\text { Number of } \\
\text { participants }\end{array}$ & $\begin{array}{l}\text { Intervention } \\
\text { duration }\end{array}$ & $\begin{array}{l}\text { Type of the knee } \\
\text { valgus brace }\end{array}$ & $\begin{array}{l}\text { Used- } \\
\text { questionnaire }\end{array}$ & $\begin{array}{l}\text { The direction of } \\
\text { effect, as indicated } \\
\text { in the manuscript }\end{array}$ \\
\hline $\begin{array}{l}\text { RobertLachaine } \\
\text { et al., } 2020 \text { [17] }\end{array}$ & $\begin{array}{l}\text { randomized } \\
\text { crossover }\end{array}$ & 24 (10f, 14 m) & 3 months & $\begin{array}{l}\text { valgus three-point } \\
\text { bending system } \\
\text { brace (V3Pbrace), } \\
\text { an unloader } \\
\text { brace with valgus } \\
\text { and external } \\
\text { rotation functions } \\
\text { (VERbrace) and a } \\
\text { stabilizing brace }\end{array}$ & $\begin{array}{l}\text { WOMAC } \\
\text { KOOS }\end{array}$ & $\uparrow$ \\
\hline $\begin{array}{l}\text { Hurley et al., } 2012 \\
\text { [32] }\end{array}$ & prospective cohort & $24(4 f, 20 m)$ & 6 months & $\begin{array}{l}\text { Breg Fusion valgus } \\
\text { unloader braces } \\
\text { (custom-made) }\end{array}$ & $\begin{array}{l}\text { WOMAC } \\
\text { SF36 }\end{array}$ & - \\
\hline lqbal, 2014 [33] & $\begin{array}{l}\text { randomized con- } \\
\text { trolled trial }\end{array}$ & $60(24 f, 36 \mathrm{~m})$ & 6 months & $\begin{array}{l}\text { Custom-made } \\
\text { off-loading knee } \\
\text { braces }\end{array}$ & $\begin{array}{l}\text { VAS pain (mm) } \\
\text { VAS activity (\%) }\end{array}$ & $\uparrow$ \\
\hline $\begin{array}{l}\text { Richards et al., } 2005 \\
\text { [34] }\end{array}$ & crossover study & $12(5 f, 7 m)$ & 6 months & $\begin{array}{l}\text { Gll Orthotics- } \\
\text { Europe, } \\
\text { Eindhoven, The } \\
\text { Netherlands }\end{array}$ & VAS pain & $\uparrow$ \\
\hline $\begin{array}{l}\text { van Raaij, et al. } 2010 \\
\text { [35] }\end{array}$ & $\begin{array}{l}\text { randomized con- } \\
\text { trolled trial }\end{array}$ & $46(35 f, 11 \mathrm{~m})$ & 6 months & $\begin{array}{l}\text { the MOS Genu1 } \\
\text { knee brace }\end{array}$ & $\begin{array}{l}\text { WOMAC Function } \\
\text { VAS pain }\end{array}$ & $\uparrow$ \\
\hline $\begin{array}{l}\text { Ostrander et al., } \\
2016 \text { [36] }\end{array}$ & $\begin{array}{l}\text { randomized con- } \\
\text { trolled trial }\end{array}$ & $16(8 f, 8 \mathrm{~m})$ & 24 weeks & $\begin{array}{l}\text { a medial-unloader } \\
\text { brace (Fusion OA; } \\
\text { Breg, Inc) }\end{array}$ & $\begin{array}{l}\text { KOOS } \\
\text { VAS pain }\end{array}$ & $\uparrow$ \\
\hline $\begin{array}{l}\text { Hjartarson and } \\
\text { Toksvig-Larsen, } \\
2018 \text { [12] }\end{array}$ & $\begin{array}{l}\text { randomized con- } \\
\text { trolled trial }\end{array}$ & $\begin{array}{l}52 \text { out } 74 \text { finished } \\
\text { one year study }\end{array}$ & One year & $\begin{array}{l}\text { Unloader One }^{\circledR} \\
\text { Knee Brace } \\
\text { (Ossur,Iceland) }\end{array}$ & KOOS & - \\
\hline $\begin{array}{l}\text { Sattari\&Ashraf,2011 } \\
\text { [37] }\end{array}$ & $\begin{array}{l}\text { randomized con- } \\
\text { trolled trial }\end{array}$ & 20 (63\%f, 37\%m) & 9 months & $\begin{array}{l}\text { The generation II of } \\
\text { knee orthosis }\end{array}$ & VAS pain & $\uparrow$ \\
\hline
\end{tabular}

Cochrane risk-of-bias tool evaluates six items: random sequence generation, blinding of participants and personnel, blinding of outcome assessment, incomplete outcome data, selective reporting and other sources of bias. Each item is judged as being in one of three categories: low (low risk of bias), high (high risk of bias), and unclear (lack of information or uncertainty about the potential for bias). 'Low' indicates a superior quality study, whereas 'high' indicates methodology of inferior quality.

\section{Results}

A total of 986 potentially relevant records were identified through the systematic literature search of electronic databases. After removing duplicates, 806 unique records were assessed for eligibility (Fig. 1). From these, 770 records were excluded after the title and abstract screening, and another 12 were excluded after full-text screening. Finally, 24 records fulfilled the inclusion criteria ( 579 participants, average age $57 \pm 5.5$ years, average body mass index $26 \pm 2.1 \mathrm{~kg} / \mathrm{m} 2$ ). Only seven of them are randomized control studies and the rest either crossover studies or prospective studies (Table 1). Those studies evaluated the effect of knee valgus brace on pain and/ or activity level over different time intervals: short term use (less than three months), moderate term use (three to six months), and long-term use (more than six months) among participants with medial compartment knee OA (Table 1).

\section{Short term use (up to three months)}

Most of the available studies evaluated the effect of using the knee brace on pain and activity level within short term one month ( 9 studies), two months ( 8 studies) and three months (3 studies) (Table 1). All of them support using the knee valgus brace as a conservative intervention for patients with medial knee OA to reduce pain and increase activity level $[1,6,7,16-18,21,23-26,28-31]$.

Within one month, Jones et al. [6] evaluated 28 participants with knee valgus brace and lateral wedge insole. Each condition was used for two weeks with two weeks washout between the two conditions. The results show that a knee valgus brace with a 6-degree knee valgus sitting reduces the pain and improves the activity level significantly $(p=0.00)$ compared to the baseline (no interventions). Fu et al., 2015 [21] also evaluated 10 participants with six different interventions for four-weeks 
with no wash-out period. The knee valgus brace significantly reduced the pain by $20 \%$ in WOMAC and $15.5 \%$ in VAS compared to the baseline. Barnes et al., [27] examined 30 patients with medial knee OA for 8 weeks with knee valgus brace and indicated the pain and activity also improved significantly based on the SF-36 questionnaire. Furthermore, $41 \%$ of them still use the brace after the investigation, while $35 \%$ of them stopped using the brace because of poor fitting or discomfort. After 5 weeks, Briggs et al., Draganich et al. and Laroche et al. [18, 25, 29] studies indicated that the pain and activity significantly improved based on WOMAC and SF-36 in comparison with the no-brace condition. After three months of using the knee valgus brace, both the WOMAC and KOOS scores improved $10-40 \%$ on average [17].

In contrast, among these studies, some patients had controversial responses with using the knee valgus brace. In 2007, Ramsey et al. [7] evaluated 16 patients with a neutral brace and 4-degrees knee valgus brace. Each condition was used for two weeks (with two weeks wash-out period between the two conditions). The pain and the activity level were measured using the KOOS questionnaire. The results show that the knee valgus brace could improve pain and activity level but not significantly. This result could be due to the bracing order was not randomized. Moreover, 6 participants (out of 16 participants) complained of a feeling of slipping down the brace [23], and $25 \%$ of the participants stop using the brace because they had minor compliance such as redness, blisters, poor fitting, and pain [26]. In further, some users complain form knee flexion limitation during walking with the knee valgus brace which is not very comfortable for them $[6,21,24,31]$.

\section{Moderate term use (four months to Six Months)}

After six months of using the knee valgus brace, positive results were also suggested by six studies (two of them are randomized controlled studies). Briggs et al. [25] study showed that $25 \%$ of medial knee OA participants have less pain and only 12 patients had knee surgery after six months of using the knee valgus brace. Moreover, Iqbal, 2014 [33] study assessed Mistry Pakistani patients with medial knee OA for six months with knee valgus brace and found that both the pain and function improved significantly $(p=0.00)$. However knee valgus brace is effective to improve pain and function, five participants of 120 had poor fitting and swelling [33]. Similarly, Richards et al. and Ostrander et al. [34, 36] showed that the knee valgus brace is an effective conservative intervention for carefully selected patients.

In contrast, Hurley et al., 2012 [32] stated that using a knee valgus brace could improve the pain and activity level but not significantly $(p=0.05$ and $p=0.08$, respectively) based on WOMAC. This result could be explained by the high body mass index of the participant in that study $(31.8 \pm 5.2 \mathrm{~kg} / \mathrm{m} 2)$ and a short average brace wearing duration (average $4.7 \mathrm{~h}$ per day). In further, van Raaij, et al. [35] also found that patients with knee OA wear the knee valgus brace for few hours per day due to feeling less comfortable.

\section{Long term use (more than six months)}

Only three studies (two of them are randomized controlled trials) evaluated the long-term benefits of using the knee valgus brace between2000-2020 and their results also support using the knee valgus brace (Table 1 ). Hjartarson and Toksvig-Larsen, 2018[12] evaluated 149 patients with unilateral knee OA who randomly divided into brace group $(n=74)$ and placebo group $(n=75)$. After one year, both groups show improvement in pain and function, but the improvement among the brace group was more significantly based on KOOS $(p=0.00)$. Only 25 participants dropped out from the brace group because they underwent knee surgery or had problems with using the brace. Sattariand Ashraf, [37] ran a randomized controlled study on unilateral knee OA. The participants were randomly divided into three groups: brace group, insole group and control group. After nine months the brace had pain relief compared to the control group $(p=0.02)$. Furthermore, Ornetti et al., 2015 [30] also evaluated their participants after one year of using the knee valgus brace and suggested that $76 \%$ of them had significant improvement in pain and activity level (effect size more than 0.8).

\section{Reporting quality assessment}

The Strengthening the Reporting of Observational Studies in Epidemiology tool was used to evaluate the quality of the accepted articles. Concerning the title and abstract, all the accepted studies have informative abstracts that were well reported, except for some studies $[7,16,23,27,29,34]$ the abstracts were very brief and not enough information about the results. Regarding the introduction, all of the accepted articles explained the background and the object of the study, except for two studies [18] and Fu et al. [21], the background was brief. In the method section, the study design, participants' criteria, and data collection process were clearly identified. From the eligible 24 studies, only 10 studies were randomized controlled trials ( 6 of them with a control group); thus, a high chance of bias was associated with the 14 studies because they did not have a control group or the non-randomized studies. In the result section, the results were well reported in all studies except for two studies [7, 18] they did not mention the details about the recruited participants such as gender or age. 
In the discussion, all studies indicated and discussed the key points of the findings. Concerning limitations, all studies stated the limitations, except for $[6,7,16,23,27$, 34]. Regarding the source of funding, out of 24 studies, 15 studies received external grant and fund and reported the source of the fund and the role of the funders $[1,6,7,16-$ $18,22,24-30,36,38]$.

For the seven randomized controlled studies, the Cochrane risk-of-bias tool was used (Additional file 1: Appendix 2). The overall biases associated with these results were high especially the performance bias and detection bias as neither the researchers nor the participants were blind about the given interventions.

\section{Discussion}

The available knee orthoses for medial compartment knee OA are numerous. The knee valgus brace is one of the used interventions for patients with medial knee OA to reduce pain and improve activities. This type of brace aims to reduce the knee varus moment through two different mechanisms: applying a three-point pressure system (bending system) directly to the knee joint or through applying valgus force and external rotation. This kind of brace shows better clinical outcomes than soft brace and rest sleeve because of moderate-term reduction of pain and disabilities [38-40],. However, the potential benefits of using this brace are still not clear with low level of evidences. Thus, this study aims to extensively cover the available publications (in the last 20 years) that evaluate the effects of using the knee valgus brace on pain and activity level.

After systematically reviewing the available studies, the outcomes of this study found that the majority of the available studies agree that using a knee valgus brace but with some side effects and fair complications. For instance, Ornetti et al. [30] study found that patients used to wear the brace for more than $8 \mathrm{~h}$ per day initially, but then the time of wearing reduced to almost $6 \mathrm{~h}$ per day after one year due to pain, discomfort, skin problems, or excessive pressure at the front of the tibia. However, $98.6 \%$ of patients have pain relief by using a knee valgus brace [40], some patients stop using the brace due to discomfort, skin irritation, poor fitting, poor appearance, had severe pain that the brace cannot reduce $[6,21,24$, $26,30,36]$.

Moreover, the finding of this investigation noticed that the knee valgus brace could be suitable for some patients more than others. For instance, Barnes et al., [27] suggested that patients who have severe Kellgren-Lawrence grade (KL) grade and higher body mass index 28-30 stopped using the knee valgus brace, whereas patients with lower KL grade (grade II) and BMI between 20-24 still use the brace. Obese participants complain of rotation and skin irritation due to poor fitting. Participants with severe knee OA (KL grade IV) were less satisfied with using the knee valgus brace and found it less effective $[6,24]$. Thus, using the knee valgus brace could be more recommended and suitable for the patients who have less than 8 degrees of knee varus, less than 20 degrees knee flexion contracture, mild to moderate knee OA level (KL grade II and III), and their body mass index less than $30[6,27,36]$.

As a result, it is still important to provide a guideline for orthotists and therapists about the patients' criteria that could fit properly with the knee valgus brace (such as body mass index, pain level, knee varus angel, and other factors). Moreover, it is critical to provide clear information for patients about the duration of wearing and how to deal with related complications. Besides, it is necessary to try the brace on before buying for a few days to avoid disappointment as it is not a cheap intervention.

\section{The limitations}

The used studies for this study have some limitations. Most of the studies had short-term follow-up, a small sample, no control group, and a low level of evidence. Few of them are randomized control studies with a moderate level of evidence. Therefore, it is important to investigate the long-term effect of knee valgus braces with randomized-control studies with high validity questionnaires and high-quality methodology. Additionally, further researches are required to identify the optimal patients who can get the maximum benefit of wearing the knee valgus brace (such as age, gender, BMI, knee varus angle, KL grade, pain level, brace wearing duration).

The limitation of this study was including both the randomized and non-randomized studies. The decision to include all types of studies was due to the limited number of randomized studies that focus on the effect of the knee valgus brace on pain and activity level. Also, it was difficult to include only the randomized studies as they have some dissimilarities in term of control group features, the used questionnaire, the study procedure, and the duration of using the brace. In further, this study focused on evaluating activity level through questionnaires (the self-reported) not by objective methods, such as activity monitors, because mainly using questionnaires is faster, cheaper, and easier for researchers than using activity monitors. However, future studies could be run and include activity level that evaluated my objective methods. 


\section{Conclusion}

To sum up, the results of this study found that knee valgus brace could be an effective intervention for specific patients to reduce pain and improve activity level but with fair compliance. However, the long-term effect still not clear, and more researches are required to fill the gaps. This finding could be important for specialists who work with patients with medial compartment knee OA to provide sufficient information about the knee valgus brace for the patients before recommending the knee valgus brace to ensure the best quality of life and pain management.

\section{Supplementary Information}

The online version contains supplementary material available at https://doi. org/10.1186/s12891-021-04513-0.

Additional file 1: Appendix 1. Searching Protocol. Appendix 2. Risk of bias summary: review authors'judgments about each risk of bias item for each included study.

\section{Authors' contributions}

With the submission of this manuscript I would like to confirm that all authors of this paper have directly participated in the planning, execution, and analysis of this study. All authors of this paper have read and approved the final version submitted, and they have no conflict of interest.

\section{Funding}

The research was financed by the Thematic Excellence Program 2020_-Institutional Excellence Sub-programme / National Excellence Sub-program of the Ministry for Innovation and Technology in Hungary, within the framework of the 2. thematic and Biomedical Engineering programme of the University of Pécs. Code: 2020-4.1.1-TEP2020.

\section{Availability of data and materials}

Data sharing does not apply to this article as no datasets were generated or analyzed during the current study.

\section{Declarations}

Ethics approval and consent to participate

Not applicable.

\section{Consent for publication}

Not applicable.

\section{Competing interests}

The authors declare that they have no competing interests (financial and non-financial).

\section{Author details}

${ }^{1}$ Doctoral School of Health Sciences, Faculty of Health Sciences, University of Pécs, Vörösmarty utca 4, 7621 Pécs, Hungary. ${ }^{2}$ Biomedical Sciences, University of Strathclyde, Glasgow, UK. ${ }^{3}$ Faculty of Health Sciences, Institute for Health Insurance, University of Pecs, Pécs, Hungary. ${ }^{4}$ Clinical Center, Medical School, Cochrane Hungary, University of Pécs, Pécs, Hungary. ${ }^{5}$ Institute of Physiotherapy and Sport Science, Faculty of Health Sciences, University of Pécs, Pécs, Hungary.

Received: 22 February 2021 Accepted: 8 June 2021

Published online: 12 August 2021

\section{References}

1. Haladik JA, VasileffWK, Peltz CD, Lock TR, Bey MJ. Bracing improves clinical outcomes but does not affect the medial knee joint space in osteoarthritic patients during gait. Knee Surg Sports Traumatol Arthrosc. 2014:22(11):2715-20.

2. Schipplein OD, Andriacchi TP. Interaction between active and passive knee stabilizers during level walking. J Orthop Res. 1991;9(1):113-9.

3. Birmingham TB, Kramer JF, Kirkley A, Inglis JT, Spaulding SJ, Vandervoort AA. Knee bracing for medial compartment osteoarthritis: effects on proprioception and postural control. Rheumatology (Oxford). 2001;40(3):285-9.

4. Peat G, McCarney R, Croft P. Knee pain and osteoarthritis in older adults: a review of community burden and current use of primary health care. Ann Rheum Dis. 2001;60(2):91-7.

5. Guillemin F, Rat AC, Mazieres B, Pouchot J, Fautrel B, Euller-Ziegler L, et al. Prevalence of symptomatic hip and knee osteoarthritis: a two-phase population-based survey. Osteoarthritis Cartilage. 2011;19(11):1314-22.

6. Jones RK, Nester CJ, Richards JD, Kim WY, Johnson DS, Jari S, et al. A comparison of the biomechanical effects of valgus knee braces and lateral wedged insoles in patients with knee osteoarthritis. Gait Posture. 2013;37(3):368-72.

7. Ramsey DK, Briem K, Axe MJ, Snyder-Mackler L. A mechanical theory for the effectiveness of bracing for medial compartment osteoarthritis of the knee. J Bone Joint Surg Am. 2007;89(11):2398-407.

8. Bellamy N, Buchanan WW, Goldsmith CH, Campbell J, Stitt LW. Validation study of WOMAC: a health status instrument for measuring clinically important patient relevant outcomes to antirheumatic drug therapy in patients with osteoarthritis of the hip or knee. J Rheumatol. 1988;15(12):1833-40.

9. Collins NJ, Prinsen CA, Christensen R, Bartels EM, Terwee CB, Roos EM. Knee Injury and Osteoarthritis Outcome Score (KOOS): systematic review and meta-analysis of measurement properties. Osteoarthritis Cartilage. 2016:24(8):1317-29.

10. Hawker GA, Mian S, Kendzerska T, French M. Measures of adult pain: Visual Analog Scale for Pain (VAS Pain), Numeric Rating Scale for Pain (NRS Pain), McGill Pain Questionnaire (MPQ), Short-Form McGill Pain Questionnaire (SF-MPQ), Chronic Pain Grade Scale (CPGS), Short Form-36 Bodily Pain Scale (SF-36 BPS), and Measure of Intermittent and Constant Osteoarthritis Pain (ICOAP). Arthritis Care Res (Hoboken). 2011;63(Suppl 11):S240-52.

11. Ware JE, Jr., Sherbourne CD. The MOS 36-item short-form health survey (SF-36). I. Conceptual framework and item selection. Med Care. 1992;30(6):473-83.

12. Hjartarson HF, Toksvig-Larsen $\mathrm{S}$. The clinical effect of an unloader brace on patients with osteoarthritis of the knee, a randomized placebo controlled trial with one year follow up. BMC Musculoskelet Disord. 2018;19(1):341.

13. Roos EM, Roos HP, Lohmander LS, Ekdahl C, Beynnon BD. Knee Injury and Osteoarthritis Outcome Score (KOOS)-development of a self-administered outcome measure. J Orthop Sports Phys Ther. 1998;28(2):88-96.

14. Bannuru RR, Osani MC, Vaysbrot EE, Arden NK, Bennell K, BiermaZeinstra SMA, et al. OARSI guidelines for the non-surgical management of knee, hip, and polyarticular osteoarthritis. Osteoarthritis Cartilage. 2019;27(11):1578-89.

15. Pham T, Van Der Heijde D, Lassere M, Altman RD, Anderson JJ, Bellamy N, et al. Outcome variables for osteoarthritis clinical trials: The OMERACTOARSI set of responder criteria. J Rheumatol. 2003;30(7):1648-54.

16. Gaasbeek RD, Groen BE, Hampsink B, van Heerwaarden RJ, Duysens J. Valgus bracing in patients with medial compartment osteoarthritis of the knee. A gait analysis study of a new brace. Gait Posture. 2007;26(1):3-10.

17. Robert-Lachaine $X$, Dessery Y, Belzile EL, Turmel S, Corbeil P. Three-month efficacy of three knee braces in the treatment of medial knee osteoarthritis in a randomized crossover trial. J Orthop Res. 2020;38(10):2262-71.

18. Draganich L, Reider B, Rimington T, Piotrowski G, Mallik K, Nasson S The effectiveness of self-adjustable custom and off-the-shelf bracing in the treatment of varus gonarthrosis. J Bone Joint Surg Am. 2006;88(12):2645-52

19. Vandenbroucke JP, von Elm E, Altman DG, Gotzsche PC, Mulrow CD, Pocock SJ, et al. Strengthening the Reporting of Observational Studies in Epidemiology (STROBE): explanation and elaboration. Int J Surg. 2014;12(12):1500-24.

20. Vandenbroucke JP, von Elm E, Altman DG, Gotzsche PC, Mulrow CD, Pocock SJ, et al. Strengthening the Reporting of Observational Studies in 
Epidemiology (STROBE): explanation and elaboration. Ann Intern Med. 2007;147(8):W163-94.

21. Fu HC, Lie CW, Ng TP, Chen KW, Tse CY, Wong WH. Prospective study on the effects of orthotic treatment for medial knee osteoarthritis in Chinese patients: clinical outcome and gait analysis. Hong Kong Med J. 2015;21(2):98-106.

22. Pollo FE, Otis JC, Backus SI, Warren RF, Wickiewicz TL. Reduction of medial compartment loads with valgus bracing of the osteoarthritic knee. Am J Sports Med. 2002:30(3):414-21.

23. Schmalz T, Knopf E, Drewitz H, Blumentritt S. Analysis of biomechanical effectiveness of valgus-inducing knee brace for osteoarthritis of knee. J Rehabil Res Dev. 2010;47(5):419-29.

24. Hsieh LF, Lin YT, Wang CP, Liu YF, Tsai CT. Comparison of the effect of Western-made unloading knee brace with physical therapy in Asian patients with medial compartment knee osteoarthritis-A preliminary report. J Formos Med Assoc. 2020;119(1 Pt 2):319-26.

25. Briggs KK, Matheny LM, Steadman JR. Improvement in quality of life with use of an unloader knee brace in active patients with OA: a prospective cohort study. J Knee Surg. 2012;25(5):417-21.

26. van Egmond N, van Grinsven S, van Loon CJM. Is there a difference in outcome between two types of valgus unloading braces? A randomized controlled trial Acta OrthopædicaBelgica. 2017:83:690-9.

27. Barnes CL, Cawley PW, Hederman B. Effect of CounterForce brace on symptomatic relief in a group of patients with symptomatic unicompartmental osteoarthritis: a prospective 2-year investigation. Am J Orthop (Belle Mead NJ). 2002;31(7):396-401.

28. Thoumie P, Marty M, Avouac B, Pallez A, Vaumousse A, Pipet LPT, et al. Effect of unloading brace treatment on pain and function in patients with symptomatic knee osteoarthritis: the ROTOR randomized clinical trial. Sci Rep. 2018;8(1):10519.

29. Laroche D, Morisset C, Fortunet C, Gremeaux V, Maillefert JF, Ornetti P. Biomechanical effectiveness of a distraction-rotation knee brace in medial knee osteoarthritis: preliminary results. Knee. 2014;21(3):710-6.

30. Ornetti P, Fortunet C, Morisset C, Gremeaux V, Maillefert JF, Casillas JM, et al. Clinical effectiveness and safety of a distraction-rotation knee brace for medial knee osteoarthritis. Ann Phys Rehabil Med. 2015;58(3):126-31.

31. Arazpour M, Bani MA, Maleki M, Ghomshe FT, Kashani RV, Hutchins SW. Comparison of the efficacy of laterally wedged insoles and bespoke unloader knee orthoses in treating medial compartment knee osteoarthritis. Prosthet Orthot Int. 2013;37(1):50-7.

32. Hurley ST, Hatfield Murdock GL, Stanish WD, Hubley-Kozey CL. Is there a dose response for valgus unloader brace usage on knee pain, function, and muscle strength? Arch Phys Med Rehabil. 2012;93(3):496-502.

33. Iqbal MADIHA. Comparison of the effectiveness of knee braces and lateral wedge insole in the management of medial compartment knee osteoarthritis. J Med Health Sci. 2014;8(1):37-40.

34. Richards JD, Sanchez-Ballester J, Jones RK, Darke N, Livingstone BN. A comparison of knee braces during walking for the treatment of osteoarthritis of the medial compartment of the knee. J Bone Joint Surg Br. 2005;87(7):937-9.

35. van Raaij TM, Reijman M, Brouwer RW, Bierma-Zeinstra SM, Verhaar JA. Medial knee osteoarthritis treated by insoles or braces: a randomized trial. Clin Orthop Relat Res. 2010;468(7):1926-32.

36. Ostrander RV, Leddon CE, Hackel JG, O'Grady CP, Roth CA. Efficacy of unloader bracing in reducing symptoms of knee osteoarthritis. Am J Orthop (Belle Mead NJ). 2016;45(5):306-11.

37. Sattari S, Ashraf AR. Comparison the effect of 3 point valgus stress knee support and lateral wedge insoles in medial compartment knee osteoarthritis. Iran Red Crescent Med J. 2011;13(9):624-8.

38. Moyer RF, Birmingham TB, Bryant DM, Giffin JR, Marriott KA, Leitch KM Valgus bracing for knee osteoarthritis: a meta-analysis of randomized trials. Arthritis Care Res (Hoboken). 2015;67(4):493-501.

39. Beaudreuil J, Nizard R, Thomas T, Peyre M, Liotard JP, Boileau P, et al. Contribution of clinical tests to the diagnosis of rotator cuff disease: a systematic literature review. Joint Bone Spine. 2009;76(1):15-9.

40. Feehan NL, Trexler, G. S., \& Barringer, W. J. . The effectiveness of offloading knee orthoses in the reduction of pain in medial compartment knee osteoarthritis: a systematic review. J Prosthetics Orthotics. 2012;24(1):39-49.

\section{Publisher's Note}

Springer Nature remains neutral with regard to jurisdictional claims in published maps and institutional affiliations.
Ready to submit your research? Choose BMC and benefit from:

- fast, convenient online submission

- thorough peer review by experienced researchers in your field

- rapid publication on acceptance

- support for research data, including large and complex data types

- gold Open Access which fosters wider collaboration and increased citations

- maximum visibility for your research: over $100 \mathrm{M}$ website views per year

At BMC, research is always in progress.

Learn more biomedcentral.com/submissions 